\title{
Analysis of integrated logistics support (ILS) in the shipbuilding industry. Advantages and improvement opportunities for the naval industry. COTECMAR case study
}

Análisis del soporte logístico integrado (ILS) en la industria astillera. Ventajas y oportunidades de mejora para la industria naval. Estudio caso COTECMAR

DOI: https://doi.org/10.25043/19098642.211

Lissette P Casadiego Miranda ${ }^{1}$ Edinson A Bastos Blandón ${ }^{2}$ Edwin Paipa Sanabria ${ }^{3}$

Mónica Ruiz Pianeta ${ }^{4}$ Javier S Pinzón Ramírez ${ }^{5}$ Nelson F Zúñiga Portillo ${ }^{6}$

\begin{abstract}
Integrated Logistics Support (ILS) applied in the world-class shipbuilding industry has set significant trends in the processes and life cycles of the products and/or systems developed. COTECMAR as a Countrywide pioneer company in this sector, with specific strengths in naval prototypes, has been developing actions together with the National Navy to integrate concepts related to ILS, in its processes. Therefore, a detailed analysis of how these processes are facing the requirements of such support, has become necessary, starting from the initial basis of the possible advantages and opportunities for improvement that this could bring to the corporation and the sector. This is based on the theoretical and conceptual foundations in the ILS framework and how these are developed in the company under analysis.
\end{abstract}

Key words: Integrated Logistic Support, Life Cycle, shipbuilding industry.

\section{Resumen}

El Soporte Logístico Integrado (ILS) aplicado en la industria astillera de clase mundial ha marcado tendencias significativas en los procesos de esta y en los ciclos de vida de los productos y/o sistemas desarrollados. COTECMAR como empresa pionera del país en este sector con fortalezas especificas en prototipos navales viene desarrollando acciones junto con la Armada Nacional para integrar en sus procesos conceptos relacionados con ILS, por lo que se ha hecho necesario realiza un análisis detallado de cómo están mencionados procesos frente a los requerimientos de dicho soporte, partiendo de la base inicial de las posibles ventajas y oportunidades de mejora que esto le podría traer a la corporación y al sector, lo anterior partiendo de los fundamentos teóricos y conceptuales en el marco del ILS y como estos se desarrollan en la empresa objeto del análisis.

Palabras claves: Apoyo Logístico Integrado, Ciclo de vida, industria naval.

Date Received: October $10^{\text {th }} 2020$ - Fecha de recepción: Octubre 10 de 2020

Date Accepted: January 14 $4^{\text {th }} 2021$ - Fecha de aceptación: Enero 14 de 2021

\footnotetext{
${ }^{1}$ Escuela Naval de Suboficiales A.R.C. Barranquilla, Colombia. Email: lissettecasa@hotmail.com

${ }^{2}$ Escuela Naval de Suboficiales A.R.C. Barranquilla, Colombia. Email: edinson.bastos@armada.mil.co

${ }^{3}$ COTECMAR. Cartagena, Colombia. Email: epaipa@cotecmar.com

${ }^{4}$ COTECMAR. Cartagena, Colombia. Email: mruiz@cotecmar.com

${ }^{5}$ COTECMAR. Cartagena, Colombia. Email: jpinzon@cotecmar.com

${ }^{6}$ Escuela Naval de Suboficiales A.R.C. Barranquilla, Colombia. Email: nefazuniga_@hotmail.com
} 


\section{Introduction}

Over the years, industries have increased the number of factors involved in improving their activities and/or processes, and their relationships with clients and/or suppliers.

As a result of the increase in client requirements and expectations, manufacturing practices are improved and product quality is enhanced. In the case of after-sales services, the industry has gradually advanced with strategies such as scheduled maintenance, preventive maintenance, or warranty support, among other aspects. To meet each of these strategies, the conditions of each company must be studied to comply with what is offered to the client.

In the industry of complex systems, such as aircraft, ships and/or submarines, which have a useful life of over thirty years, after-sales service plans are a rigorous task, which is enabled by strengthening the processes in the industry, considering the company's stakeholders (internal client and external client), resulting in a process that generates benefits for both the company and the customer.

The main objective of the analysis was to establish the advantages and opportunities for improvement for the naval industry and specifically for the company under study, COTECMAR. To achieve it, theoretical foundations were approached from a conceptual point of view, describing the ILS from the perspective of different authors, which simplified a global vision of this program. For this purpose, some authors were identified with the largest number of publications on this subject, specifically in the naval industry. Based on the theoretical analysis and the study of the logistic performance of the countries, some improvement opportunities were established for the Latin American naval industry and specifically for COTECMAR.

\section{Theoretical discussion}

ILS is defined as the set of management and technical processes, through which hardware or software considerations are integrated from early stages throughout the life cycle, enabling the planning, acquisition, implementation, evaluation and care of logistical elements, in search of cost and time effectiveness (NATO, 2011).

In 1981, the Defense Acquisition Improvement Program (Department of Defense, 1986) was born, with it the ILS policy focused on a joint development of logistics activities, leaving aside the independent management of activities.

Based on the ILS concept, for a better understanding of the logistics elements that comprise it and the relationship they have in the life cycle of a system, it is necessary to address it in greater depth. However, not all the references agree on the handling of these elements (number of elements, denominations, activities, among others).

The following is a comparison of the elements used by different authors.

The elements presented in Table 1, are described below, according to the International Guide for the Use of S-Series Integrated Logistics Support Specifications (ASD and AIA SXO0I, 2016).

Computer Resources: This element is responsible for the planning and provision of hardware, software and labor resources necessary for computer systems.

Design Influence: Is responsible for the integration of the systemic engineering design features with the other functional elements of the ILS.

Facilities and Infrastructure: This element is responsible for the management of assets and/or fixed facilities required for the integration, support, and operation of the product.

Maintenance: This element identifies, plans, records and implements the requirements for maintenance.

Manpower \& Personnel: It oversees identifying, planning, and assigning personnel with the necessary skills and aptitudes to provide support. 
Table 1. Elements of ILS in the literature based on some references.

\begin{tabular}{|c|c|c|c|c|c|}
\hline \multirow[b]{2}{*}{ Element } & \multicolumn{5}{|c|}{ Autor } \\
\hline & S-Series (i) & UK Mod (ii) & DoD (iii) & DAU (iv) & NATO (v) \\
\hline Computer Resources & $\mathrm{X}$ & & & $\mathrm{X}$ & \\
\hline Design Influence & $\mathrm{X}$ & & & $\mathrm{X}$ & $\mathrm{X}$ \\
\hline Facilities \& Infrastructure & $\mathrm{X}$ & $\mathrm{X}$ & $\mathrm{X}$ & $\mathrm{X}$ & $\mathrm{X}$ \\
\hline Maintenance & $\mathrm{X}$ & $\mathrm{X}$ & $\mathrm{X}$ & $\mathrm{X}$ & $\mathrm{X}$ \\
\hline Manpower \& Personnel & $\mathrm{X}$ & $\mathrm{X}$ & $\mathrm{X}$ & $\mathrm{X}$ & $\mathrm{X}$ \\
\hline PHS\&T & $\mathrm{X}$ & $\mathrm{X}$ & $\mathrm{X}$ & $\mathrm{X}$ & $\mathrm{X}$ \\
\hline Supply Support & $\mathrm{X}$ & $\mathrm{X}$ & $\mathrm{X}$ & $\mathrm{X}$ & $\mathrm{X}$ \\
\hline Technical Data & $\mathrm{X}$ & $\mathrm{X}$ & $\mathrm{X}$ & $\mathrm{X}$ & $\mathrm{X}$ \\
\hline Training & $\mathrm{X}$ & $\mathrm{X}$ & $\mathrm{X}$ & $\mathrm{X}$ & $\mathrm{X}$ \\
\hline Product Support Management & $\mathrm{X}$ & & & $\mathrm{X}$ & \\
\hline Sustaining Engineering & $\mathrm{X}$ & & & $\mathrm{X}$ & \\
\hline
\end{tabular}

Note: X Indicates that the author develops this element.

Source: Authors.

Packing, Handling, Storage and Transportation (PHS\& $\boldsymbol{T}$ ): addresses personnel, support equipment, raw materials, spare parts, and induction tasks developed within the PHS\&T framework.

Supply Support: its objective is to manage the processes and techniques necessary to determine supply requirements, catalogs, warehousing, spare parts management, and suppliers.

Support Equipment: its objective is to guarantee the necessary equipment to provide support during the operation.

Technical Data: aims at identifying, planning, validating, recording, and implementing actions for the development, acquisition, and maintenance of information.

Training: aims to identify, plan and record training support, to implement training strategies to operate, maintain and support the product during its life cycle, ensuring optimal performance and product utilization.

Product Support Management: consists of the elaboration of the support concept, the ILS plan and provides obsolescence reporting.
Sustaining Engineering: compares the product with its base configuration and identifies opportunities for improvement, analyzes the causes of deficiencies and evaluates the impact of corrections, proposing a range of corrective actions during operation.

The ILS Specification Council created a family of standards to establish and integrate the portfolio of specifications related to logistics elements for military and civil applications. These standards are born from the effort of different working groups integrated by personnel from the AeroSpace and Defense Industries Association of Europe (ASD) and some Ministries of Defense, which promoted the agreement on the specifications between the European and American industries (ASD and AIA Overview, 2016). This portfolio is integrated by six standards which are listed below:

S1000D, developed for the specification of technical publications and querying of common databases (ASD and AIA S1000D, 2016). Since its second version its scope was extended to land and maritime applications, as well as opening up to military and civilian systems.

S2000M presents a standard for the management of materials management processes. Topics such 
as procurement, spare parts lists and material sourcing are covered here. (ASD and AIA S2000M 2017).

S3000L, standard developed with a scope in all the processes and requirements necessary for a correct elaboration of the Logistics Support Analysis (LSA). It is one of the standards that covers more topics, including LORA, LCC and CM. (ASD and AIA, S3000L, 2014).

S4000P provides analytical methodologies for the identification and management of preventive maintenance task requirements (PMTR). In addition, it addresses an analysis of maintenance during the operation phase. (ASD and AIA S4000P, 2017).

S5000F, presents the basis for performing operational and maintenance performance analysis resulting in improved maintenance concept, support concept, detailed LCC life cycle cost information and more complex contract support management. (ASD and AIA S5000F, 2016).

S6000T, provides the basis for training needs analysis. (ASD and AIA S6000T, 2016).

The development of these six standards is based on the twelve elements mentioned in Table 1, most of which are related in a transversal manner in all the standards, which allows identifying the interaction between the documents.

In order to comply with the ILS, the development of each of the activities and tasks that make up each logistic element is required (Table 2), facilitating the understanding of the gradual development that must take place, given that there is a sequence or order established for these, which becomes a continuous feedback of the process.

In the case of the activities of each element, the inputs are presented to facilitate their realization and then the outputs that each of these should provide, thanks to this information a sequence can be organized by precedence rather than by a defined stage in the life cycle (Fig. 1).
Continuing with the analysis of references, the Ministry of Defense of the United Kingdom through its Logistics Chain Support Manual

Table 2. ILS elements and activities.

\begin{tabular}{|c|c|}
\hline ILS Element & Activities \\
\hline \multirow[t]{2}{*}{ Computer Resources } & Computer Resources Analysis \\
\hline & Provide Computer Resourses \\
\hline \multirow{3}{*}{ Design Influence } & $\begin{array}{l}\text { Reliability, Availability, } \\
\text { Maintainability Analysis }\end{array}$ \\
\hline & LSA \\
\hline & $\mathrm{LCC}$ \\
\hline \multirow{2}{*}{$\begin{array}{l}\text { Facilities and } \\
\text { Infraestructure }\end{array}$} & F\&I Analysis \\
\hline & Facilities and Infraestructure \\
\hline \multirow{8}{*}{ Maintenance } & Maintenance Concept \\
\hline & Level of Repair Analysis \\
\hline & Maintenance Tasks \\
\hline & Supportability Safety Analysis \\
\hline & Improve Preventive Maintenance \\
\hline & Schedule Maintenance \\
\hline & $\begin{array}{l}\text { Diagnostics. Prognostics and Health } \\
\text { Management Analysis }\end{array}$ \\
\hline & Software Maintenance Analysis \\
\hline $\begin{array}{l}\text { Manpower \& Personnel } \\
\text { Analysis }\end{array}$ & Manpower \& Personnel Analysis \\
\hline $\begin{array}{l}\text { Packaging, Handling, } \\
\text { Storage \& Transport }\end{array}$ & PHS\&T Requirements \\
\hline \multirow{4}{*}{$\begin{array}{l}\text { Product Support } \\
\text { Management }\end{array}$} & Manage Contract \\
\hline & Product Support Requirement \\
\hline & ILS Plan \\
\hline & Obsolescence Management \\
\hline \multirow{2}{*}{$\begin{array}{l}\text { Supply Support } \\
\text { Management }\end{array}$} & Provisioning Data \\
\hline & Material Supply \\
\hline \multirow{2}{*}{ Support Equipment } & Support Equipment Requirements \\
\hline & Support Equipment \\
\hline \multirow[b]{2}{*}{ Sustaining Engineering } & Engineering Technical Analysis \\
\hline & $\begin{array}{l}\text { Develop \& provide Engineering } \\
\text { disposition \& recommend design } \\
\text { changes }\end{array}$ \\
\hline \multirow{2}{*}{ Technical Data } & Technical Data Package \\
\hline & Technical Publications \\
\hline \multirow{4}{*}{ Training } & Training Need Analysis \\
\hline & Training Plan \\
\hline & Training Development \\
\hline & Training \\
\hline
\end{tabular}

Source: Information obtained from ASD and AIA, SX00I (2016). 
Fig. 1. Sequence diagram of ILS activities.

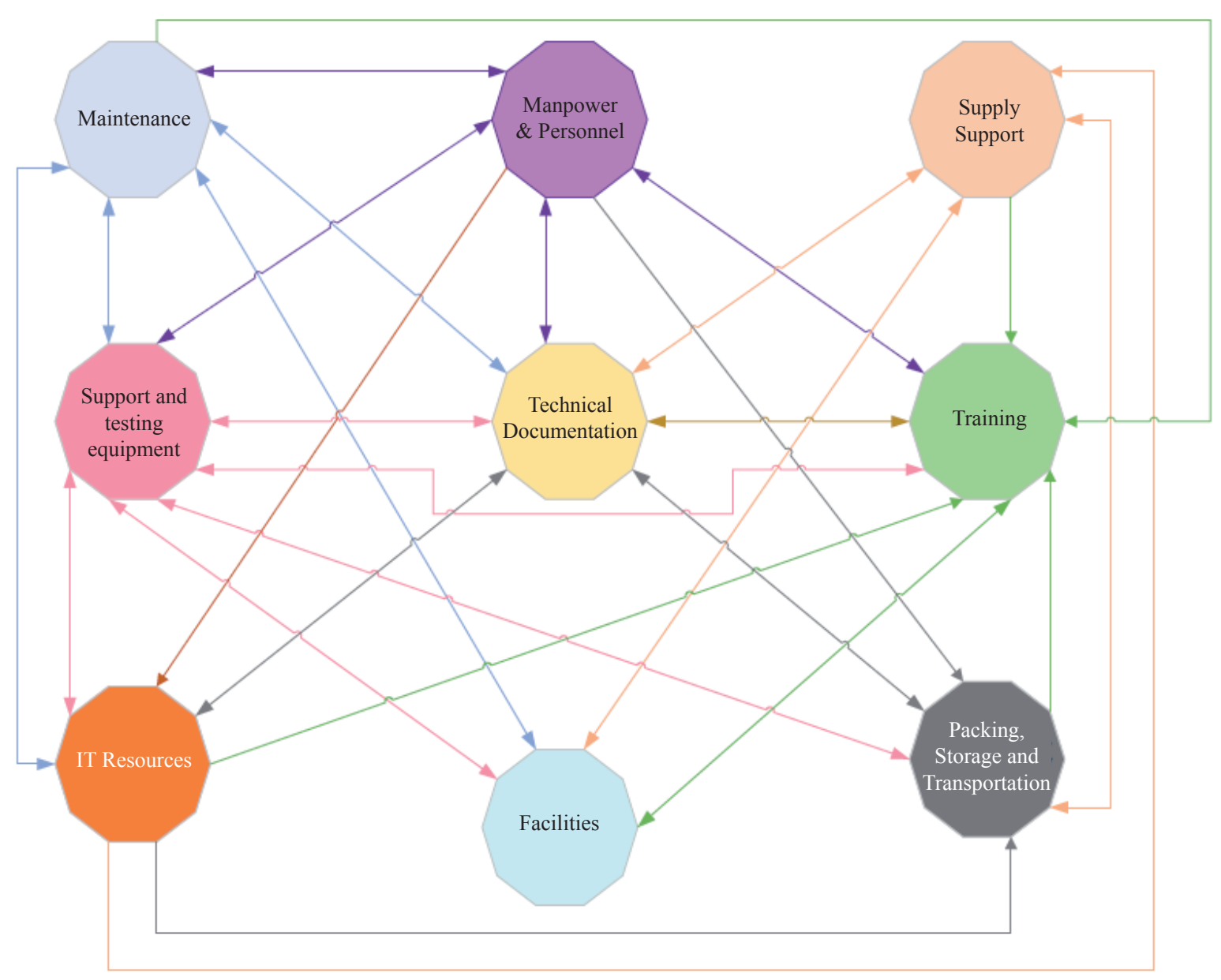

Source: Authors.

(Ministry of Defense, 2014) presents guidelines for the understanding of responsibilities in the framework of ILS development.

As can be seen in Table 1, this author does not handle the same elements as the S-Series or DAU family. One of the elements not found in other documents is "Disposal and Termination", which refers to the efficient deactivation of the product, including its spare parts and materials. The author emphasizes the importance of knowing the deactivation process of the product once its useful life cycle is over, this should be done from early stages of the design and should consider the reduction of the environmental impact to be caused.
On the other hand, as Table 1 shows, the DoD does not handle all the elements, as is the case with the Ministry of Defense of the United Kingdom. The DoD also develops other interesting elements, among which is the "Funding" element, which highlights the importance of relating the needs of the support elements with the budget and funding procedures. This activity, in conjunction with other equipment programs, allows a more accurate forecast for the determination of costs during the entire life cycle. (Department of Defense, 1986).

Another referenceistheDEFENSEADQUISITION UNIVERSITY (DAU), which describes with a broad level of detail, which is not only maintained in the definition of the elements (Table 1) but 
transcends and involves other disciplines that favor the correct support of the product.

On the other hand, the NORTH ATLANTIC TREATY ORGANIZATION (NATO), better known in Latin America as OTAN "North Atlantic Treaty Organization", handles the Life Cycle Cost (LCC) element in a particular way, and presents it independently, that is, it does not classify it as an ILS element. Although the other authors analyzed in this document also involve this program, NATO highlights the importance and necessity of LCC analysis because it must be present from the beginning of the design to ensure lower cost decision making. On the other hand, it relies heavily on logistic support analysis (LSA) to obtain inputs that simulate the logistic process, cost effectiveness models and trade-off studies that favor a better life cycle cost analysis.

\section{Analysis of the Latin American context}

As its name indicates, Integrated Logistics Support is developed within the framework of logistics activities and, as already discussed in this document, it is composed of elements that enable the development of an organization's logistics activities. However, when comparing the performance of logistics activities of countries, the "Logistics Performance Index" (LPI) is used, an indicator determined by the World Bank, which interactively compares countries or regions to identify and qualitatively recognize their logistics performance. This indicator is composed of six criteria (worldbank.org, 2018), which are customs, infrastructure, ease of shipment agreements, quality of logistics services, product tracking and tracing, and times. In the case of Latin America as shown in Table 3, the first 9 countries in the ranking of this indicator can be observed, which mostly exceed the average of the 160 countries analyzed by the World Bank.

Now, how does the logistics performance index relate to Integrated Logistics Support? As can be identified, the ILS elements are focused on a
Table 3. LPI Ranking of Latin American Countries.

\begin{tabular}{|c|c|c|c|}
\hline Country & Year & LPI Rank & LPI Score \\
\hline Chile & 2018 & 34 & 3.32 \\
\hline Brazil & 2018 & 56 & 2.99 \\
\hline Colombia & 2018 & 58 & 2.94 \\
\hline Argentina & 2018 & 61 & 2.89 \\
\hline Ecuador & 2018 & 62 & 2.88 \\
\hline Paraguay & 2018 & 74 & 2.78 \\
\hline Peru & 2018 & 83 & 2.69 \\
\hline Uruguay & 2018 & 85 & 2.69 \\
\hline Venezuela, RB & 2018 & 142 & 2.23 \\
\hline
\end{tabular}

Source: THE WORLD BANK (2018).

company's own activities, it presents an internal strengthening of most of its processes, however, elements such as "Supply Support" and "PHS\&T" are closely related, based on the specific analysis carried out in this document.

When reference was made to the Supply Support element, its objectives were identified, among which it must ensure the management of its suppliers. This activity involves an interaction between the company and an external agent, as well as with the supplier. In carrying out this activity, conditions such as delivery times, mode of delivery and associated costs will have to be analyzed, both for national and international suppliers.

In the PHS\& $T$ element, the company concentrates on the tasks required for proper packaging, handling, storage and transportation. Therefore, the access routes of the products to be serviced, the mode of transportation of the materials from the supplier to the company, and the transportation of the product from the company to the customer must be analyzed.

In both cases, if the LPI criteria have a low score, it could be inferred that product delivery is more difficult and costly in the country analyzed. Therefore strengthening the internal processes of the companies is necessary, accompanied by policies that promote better logistical conditions in each country. 
The LPI ranking shows that European countries and the United States (Table 4) are within the first 20 positions, comprising $12.5 \%$ of the countries with the best logistics practices, where the companies that have participated in the development of the S-Series family standards are located.

Relationship between companies participating in the development of S-Series standards and the 2018 LPI ranking Table 4.

If Latin American companies were to implement ILS using standards such as the ones presented, they would improve their logistics processes, enhancing the competitiveness of the sector in a globalized scenario.

As a sample of this phenomenon, as a result of the growth of the naval and maritime production sector in Colombia, Decree 590 of 2018 is issued, which defines the entry of inputs and raw materials with zero tariffs (Presidency of the republic of Colombia, 2018), as a measure for streamlining the import processes of raw materials, which would influence the logistics performance indicator of the LPI, for this particular sector.

\section{The Case of COTECMAR}

COTECMAR is an innovative organization that works within the field of scientific and technological research, supporting the development of the Colombian maritime industry. Its experience in the advanced design and construction of customized naval platforms, as well as the repair and maintenance of vessels with high quality standards, technical expertise, and responsiveness in a timely manner, make it a regional benchmark.

Its influence in Latin America is identified through its export offer to countries such as Guatemala, Honduras, Costa Rica, Panama, Peru, Bolivia and Paraguay.

During 2017, the shipyard sector in Colombia generated 6,000 direct jobs and 4,363 indirect ones, thanks to its influence on fourteen other manufacturing branches such as metal mechanics, plastics, glass and chemicals, among others. (Ministry of Commerce, Industry and Tourism, 2017).

On the other hand, according to (Toro et al., 2015) there is a retribution in the operational profits of the investments made in science, technology, and innovation activities (ACTI). Even more importantly, this reference concludes that the benefits obtained for the company are greater to the extent that there is participation of all the companies in the sector.

Table 4. Relationship between companies participating in the development of S-Series standards and the 2018 LPI ranking.

\begin{tabular}{|c|c|c|}
\hline $\begin{array}{c}\text { LPI } \\
\text { Rank }\end{array}$ & Country & $\begin{array}{l}\text { Companies/Organizations } \\
\text { that have collaborated for the } \\
\text { development of the } \\
\text { S-Series standards }\end{array}$ \\
\hline \multirow{4}{*}{1} & \multirow{4}{*}{ Germany } & Airbus Bundeswehr \\
\hline & & $\begin{array}{l}\text { ESG Electronic System and } \\
\text { Logistics } \mathrm{GmbH}\end{array}$ \\
\hline & & HEME GmbH \\
\hline & & $\begin{array}{l}\text { EADS Military Systems Airbus } \\
\text { Helicopters KCIG }\end{array}$ \\
\hline 2 & Sweden & Saab AB \\
\hline 3 & Belgium & NATO \\
\hline \multirow{3}{*}{4} & \multirow{3}{*}{ Austria } & FACC AG \\
\hline & & $\begin{array}{l}\text { Austrian Aeronautics Industries } \\
\text { Group }\end{array}$ \\
\hline & & $\mathrm{FBC}$ \\
\hline \multirow{4}{*}{9} & \multirow{4}{*}{ UK } & UK Mod \\
\hline & & Augusta Westland LSC Group Ltd \\
\hline & & BAE \\
\hline & & Rolls Royce BAE Systems \\
\hline \multirow{3}{*}{14} & \multirow{3}{*}{$\begin{array}{l}\text { United } \\
\text { States }\end{array}$} & O'Neil Boeing \\
\hline & & Andromeda Systems ISS \\
\hline & & LOGSA NAVSEA/DoD \\
\hline \multirow{3}{*}{16} & \multirow{3}{*}{ France } & Airbus \\
\hline & & $\begin{array}{l}\text { Dassault Aviation Eurocopter } \\
\text { MBDA }\end{array}$ \\
\hline & & Airbus Helicopter \\
\hline 17 & Spain & $\begin{array}{l}\text { Airbus Defense and Space EADS } \\
\text { Home }\end{array}$ \\
\hline \multirow{2}{*}{19} & \multirow{2}{*}{ Italy } & SELEX EX \\
\hline & & Isselnord Finmeccanica \\
\hline
\end{tabular}

Source: Authors. Information taken from (worldbank.org, 2018). 
A study conducted (Arango et al., 2011) proposed that the modernization of logistics processes carried out by COTECMAR would mainly benefit from a productive system based on reverse logistics. Given the complexity of a vessel, achieving a reverse logistics system implies having great knowledge of the life cycles of the different components and materials that integrate the systems; this type of analysis is carried out in early stages described in the ILS references.

Based on the above, it can be deduced that the research and development activities carried out by COTECMAR together with the National Navy at the integrated logistics support (ILS) level will have a positive impact on the competitiveness of the sector and on the development of the national naval and maritime industry.

\section{Conclusions}

The implementation of ILS at the corporate level is an opportunity to define the customer's logistic requirements, allowing to know their needs and meet them in a timely manner, in the case of the naval and maritime industry, during the operation of the vessel.

The implementation of the ILS in COTECMAR would be reflected in the support to the vessel to make it reliable and maintainable during its operation impacting the national and international market (Latin America), thus increasing the technological level in research and development, logistic support processes and interaction with stakeholders such as customers and suppliers at national and international level.

On the other hand, it is important to highlight that the investment involved in the implementation of ILS would have a return that would be reflected in maintenance contracts and support to the life cycle of the vessels, as well as in the improvement of the products and services offered to its clients in the national and international naval and maritime industry.

\section{References}

ASD and AIA, Overview (2016). The S- Series ILS specifications. Brussels.

ASD and AIA, S1000D (2016). International specification for technical publications. 4th ed. [ebook] Brussels. Available at: http://s1000d. org/Pages/Home.aspx [Accessed Oct. 2018].

ASD and AIA, S2000M (2017). International specification for material management. 6th ed. [ebook] Brussels. Available at: http://www. s2000m.org/ [Accessed Oct. 2018].

ASD and AIA, S3000L (2014). International procedure specification for Logistics Support Analysis LSA. 1st ed. [ebook] Brussels. Available at: http:// www.s3000l.org/ [Accessed Oct. 2018].

ASD and AIA, S4000P (2017). International specification for developing and continuously improving preventive maintenance. 2nd ed. [ebook] Brussels. Available at: http://www. s4000p.org/ [Accessed Oct. 2018].

6. ASD and AIA, S5000F (2016). International specification for in-service data feedback. 1st ed. [ebook] Brussels. Available at: https:// www.s5000f.org/ [Accessed Oct. 2018].

ASD and AIA, S6000T (2016). International procedure specification for training/TNA. [ebook] Brussels. Available at: http://www. s6000t.org/ [Accessed Oct. 2018].

ASD and AIA, SX00I (2016). International guide for the use of the S-Series Integrated Logistic Support (ILS) specifications. [ebook] Brussels. Available at: https://www.sx000i. org/ [Accessed Oct. 2018].

Data.bancomundial.org. (2018). World Bank Open Data | Data. [Online] Available at: https://datos.bancomundial.org [Accessed Oct. 2018]. 
Analysis of integrated logistics support (ILS) in the shipbuilding industry. Advantages and improvement opportunities for the naval industry. COTECMAR case study

Department of Defense Integrated logistics Support Guide. Defense Systems Management College. 1986.

Ministry of Commerce, Industry and Trade (2017). Pro a s t ill e r o s, MinComercio's program to boost this industry. Bogotá. Available at: http:// www.mincit.gov.co/publicaciones/38122/ proastilleros_el_programa_de_mincomercio_ para_impulsar_esa_industria

Ministry of Defense. JSP 886 THE DEFENCE LOGISTIC SUPPORT CHAIN MANUAL. 2014. ATLÁNTICO NORTE. NATO International. ALP-10: NATO Guidance on Integrated Logistics Support for Multinational Armament Programmes. 2011.

Presidency of the Republic of Colombia (2018). Goods and raw materials to manufacture ships will be able to enter the country with zero tariffs. Bogotá. Available at: http://es.presidencia.gov. co/noticia/180404- Bienes-y-materias-primaspara-fabricar- barcos-podran-entresar-al-paiscon-ero- arancel.

Worldbank.org (2018). Home | Logistics Performance Index. [Online] Available at: https://lpi.worldbank.org/ [Accessed 19 Oct. 2018]. 